\title{
Effect of Spatial Distribution and Nitrogen Level on Growth Attributes of Hybrid Rice (Oryza sativa L.)
}

\author{
Nadeem Khan $^{1}$, Malik M. Ahmad ${ }^{1}$, Saba Siddiqui ${ }^{1}$, Salman Ahmad ${ }^{1}$, \\ Mubeen $^{2}$ and O.P. Rai ${ }^{3}$ \\ ${ }^{1}$ Integral Institute of Agricultural Science and Technology (IIAST), Integral University, \\ Lucknow-226 026, India \\ ${ }^{2}$ Mohammad Ali Jauhar University, Rampur, India \\ ${ }^{3}$ Department of Agronomy, Narendra Deva University of Agriculture and Technology, \\ Faizabad-224 229, India \\ *Corresponding author:
}

\section{A B S T R A C T}

Keywords

Hybrid rice,

PA 6201,

Plant spacing,

Nitrogen levels,

Growth attributes.

Article Info

Accepted:

04 April 2017

Available Online:

10 May 2017
A field trial was conducted to investigate the effect of spatial distribution and different levels of nitrogen on growth of hybrid rice variety PA 6201, comprising of 16 different treatments using randomized complete block design with three replications at agronomy research farm of Narendra Deva University of Agriculture and Technology, Faizabad (U.P.), India during the season of Kharif in the year 2012. It was found that the spacing of $20 \times 15 \mathrm{~cm}$ was found significantly superior over other geometric configurations and at par with closer spacing $20 \times 10$ $\mathrm{cm}$ for the entire growth characteristics. Application of $187.5 \mathrm{~kg} \mathrm{~N} \mathrm{ha}^{-1}$ proved to be better over other in respect to all growth attributes. There has been an increase in plant height, number of tillers, leaf area index as well as in dry matter of the plant.

\section{Introduction}

Rice, one of the most important food crops in the world, forms the staple diet of 2.7 billion people (FAOSTAT, 2007). In India, the cultivation of rice is done in an area of 44 million hectare with an average production of 90 million tonnes thereby making a productivity of 2.0 tonnes per hectare (Thiyagarajan, 2007). It is cultivated on an area of 44.1 million ha having annual production of about 131.3 million tonnes with productivity of 3.0 tonnes ha ${ }^{-1}$ (Ferrer, 2011). It accounts for about $42 \%$ of total food grain production and $55 \%$ of cereal production in the country. In Uttar Pradesh (U.P.) state, rice is grown on an area of about 5.69 million ha with a production of 11.7 million tonnes and productivity of about 2.06 tonnes $\mathrm{ha}^{-1}$. Consumption of rice is continuously growing every year and it is anticipated that in 2025, the requirement would be 140 million tonnes (Thiyagarajan, 2007). Its cultivation is of immense importance for providing food security in Asian countries, where more than $90 \%$ of the global rice is produced and 
consumed (Ferrer, 2011). To meet the demand of increasing population and maintain the self sufficiency, the present production level needs to be increased by over 2 million tonnes year ${ }^{-1}$ in coming decade (Subbaiah, 2006). To sustain present food selfsufficiency and to meet future food requirements, scientists have started to look forward for highly productive varieties. Hybrid rice yields about $15-20 \%$ more than the promising high-yielding commercial varieties (Chaturvedi, 2005). The hybrid rice has a yield advantage of at least 1 tonnes ha ${ }^{-1}$ more than the highest yielding inbred cultivars with similar maturity duration. In India, it is estimated that area under hybrid rice has increased from 10000 to 1 million hectare from year 1995 to 2006 (Viraktamath et al., 2006).

Earlier studies have revealed that the judicious and proper use of agronomic practices, especially planting geometry and use of fertilizers can markedly increase and improve the growth of rice plants. Plant space determines solar radiation interception, crop canopy coverage and total dry matter accumulation (Anwar et al., 2011). Also, several studies had shown that the closer planting may cause mutual shading which may direct to intra-specific competition that increases the problems of lodging (Bond et $a l ., 2005$ ), insect pest infestation (Tan et al., 2000) and even rat injuries (Castin and Moody, 1989). Therefore, plant spacing should be optimized by keeping in mind different aspects of cropping management techniques. Optimized plant spacing ensures proper growth of plants both above and under the ground by utilizing equal amount of solar radiation, enhancing soil respiration and providing better weed control thereby, higher crop yields (Gautam et al., 2008) and other nutrients from soil (Ashraf et al., 2014). The plant spacing can further influence variations through alteration in the attainment of phenophases and eventually the development of plant canopy (Faisul-ur-Rasool et al., 2013). In a study, wider spacing of $20 \times 15 \mathrm{~cm}$ gave higher yield as compared to crop planted with closer spacing of $20 \times 10$ and $15 \times 15 \mathrm{~cm}$ (Rajesh and Thanunathan, 2003).

Nitrogen is a key player in increasing any type of agriculture production and is one of the most yield-limiting nutrients for annual crops (Roy and Mishra 1999). Inadequate nitrogen in soils show reduced leaf area limiting light interception thereby causing reduced photosynthesis which finally has an effect on biomass growth and grain yield (Sinclair, 1990). Bacon (1980) and Inthavongra et al., (1985) showed the most appropriate time of nitrogen application to rice is panicle initiation, which produced maximum plant height, grains/panicle and grain yield. Keeping in view the importance of spatial distribution of crop plants and nitrogen levels in soil, the present study was therefore, designed to find out the response of different levels of nitrogen with respect to plant spacing on growth attributes of a hybrid rice variety PA 6201 which may play an important role in minimizing the present gap between potential and achievable growth of hybrid rice.

\section{Materials and Methods}

The field experiment was conducted during Kharif season of 2012, at Agronomy Research farm, N.D. University of Agriculture and Technology, Faizabad, U.P., India. The study area is geographically situated between $26.47^{\circ} \mathrm{N}$ latitude to $82.12^{\circ} \mathrm{E}$ longitude and at an altitude of $113 \mathrm{~m}$ above mean sea level on Faizabad-Raebareli road about $42 \mathrm{~km}$ away from Faizabad city. The climate of Faizabad district is semi-arid with hot summer and cold winter. Experimental site falls under subtropical climate in Indo-gangetic plains having alluvial calcareous soil. The 
experimental field was well leveled having good irrigation and drainage facilities. The rice variety used in the experiment was PA 6201. The experiment was laid out in a randomized complete block design with a factorial arrangement of 16 treatments replicated thrice with a net plot size of $2.20 \mathrm{x}$ $4.80 \mathrm{~m}$. The treatments consisted of 4 levels of planting spacing viz. $\mathrm{S}_{1}(20 \times 10 \mathrm{~cm}), \mathrm{S}_{2}$ $(20 \times 15 \mathrm{~cm}), S_{3}(20 \times 20 \mathrm{~cm})$ and $S_{4}(20 \times 25$ $\mathrm{cm})$. A recommended dose of entire phosphorus, potassium and zinc was applied uniformly at $60 \mathrm{~kg} \mathrm{ha}^{-1}$ through single super phosphate, $60 \mathrm{~kg} \mathrm{~K}_{2} \mathrm{O} \mathrm{ha}^{-1}$ of potash and 30 $\mathrm{kg} \mathrm{ZnSO}_{4} \mathrm{ha}^{-1}$, respectively. The effect of nitrogen level was determined by reducing $25 \%\left(\mathrm{~N}_{1}\right)$ or supplementing the recommended dose $\left(150 \mathrm{~kg} \mathrm{ha}^{-1} ; \mathrm{N}_{2}\right)$ with additional $25 \%$ $\left(\mathrm{N}_{3}\right)$ and $50 \%\left(\mathrm{~N}_{4}\right)$ nitrogen. Nitrogen was applied as per treatment through urea in three equal split doses, half as basal, one fourth as dressed at early tillering stage and the remaining a week before panicle initiation stage. The treatment details were provided in Table 1.

All the recommended agronomic practices were followed to raise a good crop. Data were recorded on a five randomly selected hills from each plot for growth characters viz., Plant height $(\mathrm{cm})$, number of tillers $\left(\mathrm{m}^{-2}\right)$, leaf area index (LAI) and dry matter accumulation $\left(\mathrm{g} \mathrm{m}^{-2}\right)$. The recorded data were further subjected to one way analysis of variance (ANOVA) techniques as suggested by Gomez and Gomes (1984). Critical difference at 0.05 probability level was worked out to compare the treatments.

\section{Results and Discussion}

\section{Effect of geometric distribution of plants and nitrogen levels on plant height and number of tillers}

Height is an index of plant growth and is known to be influenced by environmental and crop management practices. With a plant spacing of $20 \times 15 \mathrm{~cm}$, significantly taller plants with more number of tillers were recorded than wider plant spacing $20 \times 20 \mathrm{~cm}$, $20 \times 25 \mathrm{~cm}$ and with closer spacing $20 \times 10 \mathrm{~cm}$ at all the growth stages (Table 2). Nayak et $a l .$, (2003) with same hybrid rice recorded the maximum plant height and number of tiller at the similar spatial distribution of plants than spacing of $20 \times 10$ and $15 \times 15 \mathrm{~cm}$. As far as the tillers production plant $^{-1}$ is concerned, data clearly indicates that the total tillers production per plant increased with increase in row spacing, but the increase in tillers production failed to meet out beyond $20 \times 15$ $\mathrm{cm}$ of spacing and showed a reduction in the number of tillers (Table 3). Verma et al., (2002) studied the effect of spacing on hybrid rice PA 6201 and found that crop planted with $20 \times 20$ and $20 \times 15 \mathrm{~cm}$ produced significantly more number of productive tillers per $\mathrm{m}^{2}$ than the crop planted with $20 \times 10 \mathrm{~cm}$. These observations suggest that this rice variety needs an optimum plant spacing of $20 \times 15 \mathrm{~cm}$ for attaining utmost plant height and number of tillers.

An examination of data presented on plant stature with nitrogen fertilizers revealed that significant improvement in plant height and tiller production at all the growth stages viz, 30, 60, 90 DAT and at harvest. Application of $187.5 \mathrm{~kg} \mathrm{~N} \mathrm{ha}^{-1}$ registered significantly tallest plant and maximum number of tillers followed by $225 \mathrm{~kg} \mathrm{~N}^{-1}$ and lower doses (112.5 and $150 \mathrm{~kg} \mathrm{~N} \mathrm{ha}^{-1}$ ) with at all the growth stages (Table 2,3).

\section{Effect of geometric distribution of plants and nitrogen levels on plant height and number of tillers}

Height is an index of plant growth and is known to be influenced by environmental and crop management practices. With a plant spacing of $20 \times 15 \mathrm{~cm}$, significantly taller 
plants with more number of tillers were recorded than wider plant spacing $20 \times 20 \mathrm{~cm}$, $20 \times 25 \mathrm{~cm}$ and with closer spacing $20 \times 10 \mathrm{~cm}$ at all the growth stages (Table 2). Nayak et $a l .$, (2003) with same hybrid rice recorded the maximum plant height and number of tiller at the similar spatial distribution of plants than spacing of $20 \times 10$ and $15 \times 15 \mathrm{~cm}$. As far as the tillers production plant $^{-1}$ is concerned, data clearly indicates that the total tillers production per plant increased with increase in row spacing, but the increase in tillers production failed to meet out beyond $20 \times 15$ $\mathrm{cm}$ of spacing and showed a reduction in the number of tillers (Table 3). Verma et al., (2002) studied the effect of spacing on hybrid rice PA 6201 and found that crop planted with $20 \times 20$ and $20 \times 15 \mathrm{~cm}$ produced significantly more number of productive tillers per $\mathrm{m}^{2}$ than the crop planted with $20 \times 10 \mathrm{~cm}$. These observations suggest that this rice variety needs an optimum plant spacing of $20 \times 15 \mathrm{~cm}$ for attaining utmost plant height and number of tillers.

An examination of data presented on plant stature with nitrogen fertilizers revealed that significant improvement in plant height and tiller production at all the growth stages viz, 30, 60, 90 DAT and at harvest. Application of $187.5 \mathrm{~kg} \mathrm{~N} \mathrm{ha}^{-1}$ registered significantly tallest plant and maximum number of tillers followed by $225 \mathrm{~kg} \mathrm{~N} \mathrm{ha}^{-1}$ and lower doses (112.5 and $150 \mathrm{~kg} \mathrm{~N} \mathrm{ha}^{-1}$ ) with at all the growth stages (Table 2,3).

Effect of plant spacing and nitrogen levels on leaf area index and dry matter accumulation

Different spatial distribution of plants also influenced the leaf area and dry matter significantly at various growth stages. It is imperative to note that plant spacing of $20 \times 15$ $\mathrm{cm}$ produced significantly higher LAI (7.3) over the wider plant spacing of $20 \times 20 \mathrm{~cm}$ and
$20 \times 25 \mathrm{~cm}$ and at par with closer spacing $20 \times 10 \mathrm{~cm}$. Highest spacing produced lowest LAI at all the growth stages (Table 4). It is obvious from the data that LAI increased with increase in age of crop up to 90 DAT. The rate of increase LAI was very fast between 30 to 60 DAT. The data given in Table 5 clearly indicate that dry matter accumulation $\left(\mathrm{g} \mathrm{m}^{-2}\right)$ increased significantly with $20 \times 15 \mathrm{~cm}$ spacing than wider spacing $20 \times 20 \mathrm{~cm}$ and $20 \times 25 \mathrm{~cm}$ and at par with closer spacing $20 \times 10 \mathrm{~cm}$ at all the stages of crop growth.

The doses of nitrogen produced significant increase in LAI and dry matter. Application of nitrogen at $187.5 \mathrm{~kg} \mathrm{~N} \mathrm{ha}{ }^{-1}$ resulted significant increase in LAI at all the growth stages. Maximum LAI is recorded with application of $187.5 \mathrm{~kg} \mathrm{~N} \mathrm{ha}^{-1}$ which is found at par with $225 \mathrm{~kg} \mathrm{~N} \mathrm{ha}^{-1}$ at all the growth stages.

Plant growth is substantially ruled by planting density of the crop under different agroclimatic and edaphic conditions. Appropriate spatial distribution is one of the important factors to acquire higher yield in rice. In case of rice hybrids, the developmental habits of hybrid plant are distinct from conventional varieties (Siddiq, 1993). A planting density can minimize the seed necessity without reducing the overall productivity that can be managed by abundant tillering which will balance the yield. An increase in plant height might be due to the exposure of large number of plants and leaf area to sunlight during the growth period resulting in better photosynthesis and consequently increasing the plant height. Similar results have also been reported by Das et al., (1988) and Srinivasulu (1997). The increased plant height may further have been resulted due to availability of more time for growth period with optimum photoperiod and temperature for the growth of the crop plants which may effect in more nitrogen absorption for the 
synthesis of protoplasm responsible for rapid cell division which may increase the plant in shape and size. This is in line with the results of Sahu (1994), Parihar et al., (1995) and Paliwal et al., (1996).

Table.1 Details of the treatment used in the current study

\begin{tabular}{|l|l|}
\hline $\begin{array}{l}\text { Treatment } \\
\text { combination }\end{array}$ & Nitrogen levels $\left(\mathbf{k g ~ h a}{ }^{-1}\right)+$ Spacing $(\mathbf{c m})$ \\
\hline $\mathrm{T}_{1} \mathrm{~N}_{1} \mathrm{~S}_{1}$ & $25 \%$ lower than recommended dose $+20 \times 10$ \\
\hline $\mathrm{T}_{2} \mathrm{~N}_{1} \mathrm{~S}_{2}$ & $25 \%$ lower than recommended dose $+20 \times 15$ \\
\hline $\mathrm{T}_{3} \mathrm{~N}_{1} \mathrm{~S}_{3}$ & $25 \%$ lower than recommended dose $+20 \times 20$ \\
\hline $\mathrm{T}_{4} \mathrm{~N}_{1} \mathrm{~S}_{4}$ & 25\% lower than recommended dose $+20 \times 25$ \\
\hline $\mathrm{T}_{5} \mathrm{~N}_{2} \mathrm{~S}_{1}$ & ${ }^{*}$ Recommended dose $+20 \times 10$ \\
\hline $\mathrm{T}_{6} \mathrm{~N}_{2} \mathrm{~S}_{2}$ & ${ }^{*}$ Recommended dose $+20 \times 15$ \\
\hline $\mathrm{T}_{7} \mathrm{~N}_{2} \mathrm{~S}_{3}$ & ${ }^{*}$ Recommended dose $+20 \times 20$ \\
\hline $\mathrm{T}_{8} \mathrm{~N}_{2} \mathrm{~S}_{4}$ & ${ }^{*}$ Recommended dose $+20 \times 25$ \\
\hline $\mathrm{T}_{9} \mathrm{~N}_{3} \mathrm{~S}_{1}$ & $25 \%$ higher than recommended dose $+20 \times 10$ \\
\hline $\mathrm{T}_{10} \mathrm{~N}_{3} \mathrm{~S}_{2}$ & $25 \%$ higher than recommended dose $+20 \times 15$ \\
\hline $\mathrm{T}_{11} \mathrm{~N}_{3} \mathrm{~S}_{3}$ & $25 \%$ higher than recommended dose $+20 \times 20$ \\
\hline $\mathrm{T}_{12} \mathrm{~N}_{3} \mathrm{~S}_{4}$ & $25 \%$ higher than recommended dose $+20 \times 25$ \\
\hline $\mathrm{T}_{13} \mathrm{~N}_{4} \mathrm{~S}_{1}$ & $50 \%$ higher than recommended dose $+20 \times 10$ \\
\hline $\mathrm{T}_{14} \mathrm{~N}_{4} \mathrm{~S}_{2}$ & $50 \%$ higher than recommended dose $+20 \times 15$ \\
\hline $\mathrm{T}_{15} \mathrm{~N}_{4} \mathrm{~S}_{3}$ & $50 \%$ higher than recommended dose $+20 \times 20$ \\
\hline $\mathrm{T}_{16} \mathrm{~N}_{4} \mathrm{~S}_{4}$ & $50 \%$ higher than recommended dose $+20 \times 25$ \\
\hline
\end{tabular}

Table.2 Plant height of hybrid rice as influenced by plant spacing and nitrogen levels

\begin{tabular}{lllll}
\hline \multirow{2}{*}{ Treatment type } & \multicolumn{4}{c}{ Plant height $(\mathbf{c m})$} \\
\cline { 2 - 5 } & 30 DAT & 60 DAT & 90 DAT & At harvest \\
\hline Plant geometry $(\mathrm{cm})$ & 64.48 & 98.80 & 124.80 & 126.88 \\
$20 \times 10$ & 66.34 & 101.65 & 128.40 & 130.54 \\
$20 \times 15$ & 59.52 & 91.20 & 115.20 & 117.12 \\
$20 \times 20$ & 57.66 & 88.35 & 111.60 & 113.46 \\
$20 \times 25$ & 1.29 & 1.90 & 2.07 & 2.54 \\
\hline SEm \pm & 3.76 & 5.45 & 5.91 & 7.40 \\
\hline ND $(\mathrm{p}=0.05)$ & & & & \\
112.5 & 56.42 & 86.45 & 109.20 & 111.02 \\
150 & 60.76 & 93.10 & 117.60 & 119.65 \\
187.5 & 65.72 & 100.70 & 127.20 & 129.32 \\
225 & 65.10 & 99.75 & 126.00 & 128.10 \\
\hline SEm \pm & 1.29 & 1.90 & 2.07 & 2.54 \\
\hline CD $(\mathrm{p}=0.05)$ & 3.76 & 5.45 & 5.91 & 7.40 \\
\hline
\end{tabular}


Table.3 Number of tillers m-2 of hybrid rice as influenced by plant spacing and nitrogen levels at various growth stages

\begin{tabular}{lllll}
\hline Treatments & 30 DAT & 60 DAT & 90 DAT & At harvest \\
\hline Plant geometry $(\mathrm{cm})$ & & & & \\
$20 \times 10$ & 322.40 & 377.00 & 405.60 & 358.80 \\
$20 \times 15$ & 331.70 & 387.88 & 417.30 & 369.15 \\
$20 \times 20$ & 297.60 & 348.00 & 374.40 & 331.20 \\
$20 \times 25$ & 288.30 & 337.13 & 362.70 & 320.58 \\
\hline SEm \pm & 6.20 & 7.60 & 8.16 & 6.90 \\
\hline CD $(\mathrm{p}=0.05)$ & 17.92 & 21.97 & 23.57 & 19.94 \\
\hline Nitrogen level $\left(\mathrm{kg} \mathrm{ha}^{-1}\right)$ & & & \\
112.5 & 282.10 & 329.88 & 354.90 & 313.95 \\
150 & 303.80 & 355.25 & 382.20 & 338.10 \\
187.5 & 328.60 & 384.25 & 413.40 & 365.70 \\
225 & 325.50 & 380.63 & 409.50 & 362.25 \\
\hline SEm \pm & 6.20 & 7.60 & 8.16 & 6.90 \\
\hline $\mathrm{CD}(\mathrm{p}=0.05)$ & 17.92 & 21.97 & 23.57 & 19.94 \\
\hline \multicolumn{5}{r}{}
\end{tabular}

Table.4 Leaf area index of hybrid rice as subjective to the plant spacing and nitrogen levels at various growth stages

\begin{tabular}{llll}
\hline Treatments & 30 DAT & 60 DAT & 90 DAT \\
\hline Plant geometry $(\mathrm{cm})$ & & & \\
$20 \times 10$ & 3.64 & 6.92 & 7.09 \\
$20 \times 15$ & 3.75 & 7.12 & 7.30 \\
$20 \times 20$ & 3.36 & 6.38 & 6.55 \\
$20 \times 25$ & 3.26 & 6.18 & 6.34 \\
\hline SEm \pm & 0.07 & 0.13 & 0.13 \\
\hline CD $(\mathrm{p}=0.05)$ & 0.12 & 0.40 & 0.39 \\
\hline Nitrogen level (kg ha-1) & & & \\
112.5 & 3.19 & 6.05 & 6.21 \\
150 & 3.43 & 6.52 & 6.68 \\
187.5 & 3.71 & 7.05 & 7.23 \\
225 & 3.68 & 6.98 & 7.16 \\
\hline SEm \pm & 0.07 & 0.13 & 0.13 \\
\hline CD $(\mathrm{p}=0.05)$ & 0.12 & 0.40 & 0.39 \\
\hline
\end{tabular}


Table.5 Dry matter accumulation ( $\mathrm{g} \mathrm{m}-2)$ of hybrid rice as influenced by plant spacing and nitrogen levels

\begin{tabular}{lllll}
\hline Treatments & 30 DAT & 60 DAT & 90 DAT & At harvest \\
\hline Plant geometry $(\mathrm{cm})$ & & & & \\
$20 \times 10$ & 209.56 & 447.20 & 738.40 & 769.60 \\
$20 \times 15$ & 215.61 & 460.10 & 759.70 & 791.80 \\
$20 \times 20$ & 193.44 & 412.80 & 681.60 & 710.40 \\
$20 \times 25$ & 187.40 & 399.90 & 660.30 & 688.20 \\
\hline SEm \pm & 4.22 & 9.00 & 14.21 & 15.52 \\
\hline CD $(\mathrm{p}=0.05)$ & 12.21 & 25.99 & 41.04 & 44.85 \\
\hline Nitrogen level $\left(\mathrm{kg} \mathrm{ha}^{-1}\right)$ & & & \\
\hline 112.5 & 183.37 & 391.30 & 646.40 & 673.40 \\
150 & 197.47 & 421.40 & 695.80 & 725.20 \\
187.5 & 213.59 & 455.80 & 752.50 & 777.00 \\
225 & 211.58 & 451.50 & 745.60 & 740.40 \\
\hline SEm \pm & 4.22 & 9.00 & 14.21 & 15.52 \\
\hline $\mathrm{CD}(\mathrm{p}=0.05)$ & 12.21 & 25.99 & 41.04 & 44.85 \\
\hline
\end{tabular}

Hybrid rice variety growing in a close spacing may gets over-crowded due to which the plants had to compete for soil, space, nutrients, water, air and light while wider produced higher tillers per hill may resulted in weak plants. The findings are in conformity with Nayak et al., (2003), Gobi et al., (2006) and Awan et al., (2011). The total tillers per $\mathrm{m}^{2}$ in planted crop might be owing to the higher number of ear bearing shoots which might be due to better development of early form tillers up to the stage of earing because of better photosynthesis activities of the plant in the optimum photoperiod at optimum temperature to supply energy in term of photosynthate for their proper development. The productive tillers significantly may be higher in early planting due to the fact that better development of early form tillers up to reproductive phase of the crop while in case of late planting the production of tillers may take place but due to unavailability of sufficient amount of photosynthates as source of energy may result in the mortality of tillers and number of productive tillers may reduced.
Patra and Nayak (2001) found that rice crop planted with $20 \times 10 \mathrm{~cm}$ spacing produced significantly more effective tillers than the crop planted with $15 \times 10 \mathrm{~cm}$ and $10 \times 10 \mathrm{~cm}$ spacing. Rice is the major consumer of fertilizer nitrogen and gives high response to the applied nitrogenous fertilizers. One major consequence of inadequate nitrogen is reduced leaf area, thereby, limiting light interception, photosynthesis and finally biomass growth (Sinclair, 1990). The major effect of nitrogen fertilizer is to speed-up of leaf expansion rate leading to increased interception of daily solar radiation by the canopy (Squire et al., 1987). Our results had also shown higher LAI as well as dry weight matter by increasing nitrogen levels. LAI was higher because of exposer of large number of plants and leaf area to sunlight in a wider space during the growth period resulting better photosynthesis and consequently showing good growth characteristics. The higher LAI recorded might also be due to more leaves number and size. 
Dry matter accumulation increased significantly with nitrogen fertilizer application at all the growth stages of the crop. It was as expected since availability of higher vegetative growth period for development of more tillers as well as number of leaves per hill and more plant height which ultimately may have been increased by protein content thereby contributing to the dry matter of plant (Reddy, 2000). In general, dry matter accumulation increased at higher rate up to 90 days after transplanting and thereafter no significant increase was documented. Our results are in complete agreement with Mandal et al., (1992), Reddy and Reddy (1994), and Dhiman et al., (1995). The higher dry mass of nitrogen treated plants could be connected with the positive effect of nitrogen in some important physiological processes. These differences were statistically significant. However, Zhang et al., (2009) showed either more or less nitrogen before or after anthesis, respectively may increase dry matter accumulation and grain filling.

\section{Acknowledgment}

Nadeem Khan wishes to thank Prof. O P Rai, Department of Agronomy, N.D. University of Agriculture and Technology Kumarganj, Faizabad and for their kind cooperation and valuable guidance. Nadeem Khan also thanks to Dr. Meraj Khan for his critical comments in preparing manuscript.

\section{References}

Anwar, M.P., Juraimi, A.S., Puteh, A., Selamat, A., A. Man and M.A. Hakim.2011. Seeding method and rate influence on weed suppression in aerobic rice. Afr. J. Biotechnol., 10: 15259-15271.

Ashraf, U., Anjum, S.A., Ehsanullah, I. Khanand and M. Tanveer. 2014. Planting geometry-induced alteration in weed infestation, growth and yield of puddled rice. Pak. J. Weed. Sci. Res., 20: 77-89.

Awan, T.H., Ali, R.I., Manzoor, Z., Ahmad, M. and M. Akhtar 2011. Effect of different nitrogen levels and row spacing on the performance of newly evolved medium grain rice variety, KSK-133. J. Ani. Plant Sci., 21: 231234.

Bacon, P.E. 1980. Nitrogen application strategies for rice. In: Proceedings of the Australian Agronomy Conference 'Pathways to Productivity', Lawas, Australia, p. 292.

Bond, J.A., Walker, T.W., Bollich, P.K., C.H. Koger and P. Gerard.2005. Seeding rates for stale seedbed rice production in the mid southern United States. Agron. J., 97: 1560-1563

Castin, E.M. and K. Moody. 1989. Effect of different seeding rates, moisture regimes, and weed control treatments on weed growth and yield of wet- seeded rice. In: Proceedings of the $12^{\text {th }}$ AsianPacific Weed Science Society Conference, Seoul, Korea, p. 337-343.

Chaturvedi, I. 2005. Effect of nitrogen fertilizers on growth, yield and quality of hybrid rice (Oryza sativa). J. Cent. Eur. Agr., 6: 611-618.

Das, K., D. Biswal and T. Pradhan. 1988. Effect of plant density and age of seedling on the growth and yield of rice. Oryza, 25: 91-194

Dhiman, S.D., H. Om and B. Singh. 1995.Yield stabilization of scented dwarf rice under late planting through spacing and seedling age. Har. Agr. Uni. J. Res., 25: 95-99.

Faisul-ur-Rasool, R. Habib and M.I. Bhat.2013. Agronomic evaluation of rice (Oryza sativa L.) for plant spacings and seedlings per hill under temperate conditions. Afr. J. Agr. Res., 8: 46504653. 
FAOSTAT. 2007. FAO Statistical Database. http://www.fao.org

Ferrer, P.B. 1992. IRRI in India. Rice Today, 10L 22-23.

Gautam, A.K., Kumar, D., Y.S. Shivay and B.N. Mishra. 2008. Influence of nitrogen levels and plant spacing on growth, productivity and quality of two inbred varieties and a hybrid of aromatic rice. Arch. Agr. Soil Sci., 54: $515-532$.

Gobi, R., Ramesh, S., Pandian, B.J., B. Chandrasekaran and T. Sampathkumar. 2006. Evaluation of crop establishments and split application of $\mathrm{N}$ and $\mathrm{K}$ on growth, yield attributes, yield and economics of hybrid rice CoRH2. Asian J. Plant Sci., 5: 1022-1026.

Gomez, K.A. and A.A. Gomez. 1984. Statistical procedures for agricultural research. John Wiley and sons, Inc. London, UK, 2nd Edn.

Inthavongra, K., Yasve, T., Moruwaki, T., T. Watabe and K. Imai. 1985. Studies on the formation of yield and yield components in Indica rice. I. Response to nitrogen application in a local and improved varieties. Jap. J. Trop. Agr., 29: 131-139.

Mandal, N.N., P.P. Chaudhry and D. Sinha. 1990. Nitrogen, phosphorus and potash uptake of wheat (var. Sonalika). Environ. Ecol., 10: 297-300.

Nayak, B.C., B.B. Dalei and B.K. Chodhury BK.2011. Response of hybrid rice to date of planting, spacing and seedling rate during wet season. Ind. J. Agron., 48: 172-174.

Paliwal, A.K., Khandalker, V.S., P.M. Paraye and N.S. Tomar. 1996. Effect of transplanting time on grain yield and its attributes in dwarf scented rice. Ind. $J$. Agr. Sci., 66: 48-50.

Parihar, S.S., Verma, V.K., Shukla, R.K., Pandey, D., Sharma, R.B. 1995. Response of transplanted rice to planting time and nitrogen schedule. Ind. J. Agron., 40: 402-406.

Patra, A.K. and B.C. Nayak. 2001. Effect of spacing on rice varieties of various duration under irrigated condition. Ind. J. Agron., 46: 449-452.

Place, G.A., J.L. Sims and U.L. Hall.1970. Effects of nitrogen and phosphorous on the growth yield and cooking, characteristics of rice. Agron. J., 62, 239-241.

Prasad, R.A. 1990. textbook of rice agronomy. In: Nutrient management (Eds.: R. Prasad). Jain Brothers, New Delhi, p. 99-130.

Rajesh, V. and K. Thanunathan. 2003. Effect of seedling age, number and spacing on yield and nutrient uptake of traditional Kambanchamba rice. Mad. Agr. J., 90: 47-49.

Reddy, K.S. and B.B. Reddy. 1996. Effect of planting time, population density and seedling age on yield and yield parameters of rice. Ind. J. Agr. Res., 28: 171-176.

Reddy, S.R. 2001. Principles of crop production. Kalyani Publishers, Ludhiana.

Roy, D.K. and S.S. Mishra. 1999. Effect of weed management in direct-seeded, upland rice (Oryza sativa) at varying nitrogen levels. Ind. J. Agron., 44: 105108.

Sahu, D.K. 1994. Effect of date of transplanting and potassium on growth and yield of lowland rice. Oryza, 31: 38-39.

Siddiq, E.A. 1993. Rice production strategy for the $21^{\text {st }}$ century, Oryza, 30: 186-196.

Sinclair, T.N.2007. Nitrogen influence on the physiology of crop yield. In: Theoretical Production Ecology: Reflections and Prospects (Eds.: R. Rabbinge, J. Goudriaan, H. van Keulen, F.W.T.P. de Vries, H.H. van Laar). Pudoc Wageningen, p. 41-55. 
Squire, G.R., C.K. Ong and J.L. Monteith. 1987. Crop growth in semi-arid environment. In: Proceedings of $7^{\text {th }}$ International Workshop 'International Crops Research Institute for Semi-Arid Tropics', Patancheru, Hyderabad, India, p. 219-231.

Srinivasulu, K. 1997. Performance of rice hybrid under different methods and densities of planting. Oryza, 34: 73-74.

Subbaih, S.V. 2006. Several options being tapped. The Hindu-Survey of Indian Agriculture. India, p. 50.

Tan, P.S., T.Q. Khuong and N.T. Hoai. 2000. Low cost technologies for rice production in the Mekong delta. In: Proceedings at National Workshop on September 21-23. Ho Chi Minh City, Vietnam, p. 14.

Thiyagarajan, T.M. 2007. Sri in Tamil Nadu.
Current Scenario. In: Second National Symposium 'System of Rice Intensification (SRI) in India-Progress and Prospects' Agartala, Tripura, India, p. 136-138.

Verma, A.K., N. Pandey and S. Tripathi. 2002. Effect of transplanting spacing and number of seedlings on productive tillers, spikelet sterility, grain yield and harvest index of hybrid rice. Int. Rice Res. Notes, 27: 51.

Viraktamath, B.C., M.I. Ahmed and A.K. Singh. 2006. Hybrid rice for sustainable food security. Ind. Farm, 56: 25-30.

Zhang, L., Shah, L., Bouman, B.A.M., Xue, C., F. Wei and H. Tao. 2009. Response of aerobic rice growth and grain yield to $\mathrm{N}$ fertilizer at two contrasting sites near Beijing, China. Field Crop Res., 114: 45-53.

\section{How to cite this article:}

Nadeem Khan, Malik M. Ahmad, Saba Siddiqui, Salman Ahmad, Mubeen and Rai, O.P. 2017. Effect of Spatial Distribution and Nitrogen Level on Growth Attributes of Hybrid Rice (Oryza sativa L.). Int.J.Curr.Microbiol.App.Sci. 6(5): 729-738.

doi: https://doi.org/10.20546/ijcmas.2017.605.082 